\section{Assessment of Adjacent- Segment Degeneration in and Between Patients Treated with Anterior or Posterior Cervical Simple Discectomy}

\section{Anterior veya Posterior, Servikal Basit Diskektomi Geçiren Hastaların Komșu Seviye Dejenerasyonu Yönünden Değerlendirilmesi}

\begin{abstract}
AIM:The authors compared the incidence of radiologically documented and/or symptomatic adjacent segment degeneration in and between patients who underwent anterior or posterior single-level, simple discectomy.

MATERIAL and METHODS: 79 patients were clinically and radiologically examined for adjacent segment degeneration (ASD). The results were compared to evaluate which approach was predominant for adjacent segment disc degeneration.

RESULTS: ASD was found in 57 of a total of 79 patients. $24 \%$ of the patients demonstrated clinical and radiographic evidence and $48 \%$ of the patients demonstrated only radiographic evidence of ASD. Both anterior and posterior single level simple discectomy had similar rates for adjacent segment disease $(p>0,05)$. ASD was found to appear earlier in patients who had anterior cervical discectomy (4.78 vs 9.85 years, $\mathrm{p}: 0,005)$. Symptomatic evidence of ASD was found to start earlier than radiological evidence of ASD (4.67 vs 7.63 years, p:0,003). Radiographic evidence of adjacent segment degeneration was observed more commonly compared to symptomatic evidence of ASD (38 vs 19 patients, p:0.002).
\end{abstract}

CONCLUSION: Although, radiographic and clinical evidence of ASD is inevitable for both simple cervical discectomy procedures, neither anterior nor posterior simple cervical discectomy is the predominant approach for causing ASD.

KEYWORDS: Cervical spine, Cervical discectomy, Adjacent segment degeneration, Cervical disc degeneration

Öz

AMAÇ: Servikal basit diskektomi geçiren hastalarda, geç dönemde ortaya çıkabilecek komşu segment dejenerasyonunun (KSD) anterior veya posterior cerrahi yöntem açısından değerlendirilmesi.

YÖNTEM ve GEREÇ: Anterior veya posterior, tek seviye basit diskektomi geçirmiş 79 hasta, komşu segment dejenerasyonunun klinik ve radyolojik verileri doğrultusunda incelenmiştir. Sonuçlar, anterior ve posterior yaklaşım açısından değerlendirilmiştir.

BULGULAR: Anterior veya posterior basit servikal diskektomi geçiren toplam 79 hastanın 57'sinde komşu segment dejenerasyonu (KSD) bulgularına rastlanılmıştır. \%24 hastada klinik ve radyolojik, \%48 hastada ise sadece radyolojik KSD bulgularına rastlanılmıştır. Her iki yaklaşım yönteminde birbirine yakın KSD oranları saptanmıștır. ( $p>0,05)$. Anterior basit diskektomi geçiren hastalarda, KSD bulguları daha erken ortaya çıkmaktadır ( 4.78 ve 9.85 y1l, p:0,005). KSD'nun semptomatik bulguları kendisini radyolojik bulgulardan daha önce göstermektedir ( 4.67 'e karşın 7.63 yıl, p:0.003). Tüm hastalarda, KSD'nun radyolojik bulguları, klinik bulgularına göre daha sık rastlanılan bir bulgudur ( 38'e karşın 19 hasta, p:0.002).

SONUÇ: Servikal basit diskektomi uygulan hastalarda KSD kaçınılmaz bir durum olmakla birlikte, anterior veya posterior yaklaşımdan herhangi birisi, istatiksel olarak KSD oluşturma yönünden daha yatkın bir uygulama olarak bulunmamıştır.

ANAHTAR SÖZCÜKLER: Servikal omurga, Servikal diskektomi, Komşu segment dejenerasyonu, Servikal disk dejenerasyonu
Sabri Cem ACIKBAS

Cenk ERMOL

Mahmut AKYUZ

Recai TUNCER

Akdeniz University, School of Medicine, Department of Neurosurgery, Antalya, Turkey

Received : 29.09.2009

Accepted : 03.12.2009

Correspondence address: Sabri Cem ACIKBAS

Akdeniz University, School of Medicine, Department of Neurosurgery, Antalya, TURKEY

Phone : + 902422496206

E-mail : scem@akdeniz.edu.tr 


\section{INTRODUCTION}

Anterior and posterior cervical discectomy for the treatment of cervical spondylosis and cervical disc herniation demonstrate successful clinical outcomes $(2,4,10,16,21)$. Although the various complications of these procedures have been well described for many years, a new concept of accelerated degeneration at adjacent disc levels has recently been widely postulated.

The pathogenesis and clinical development of adjacent segment degeneration (ASD) following cervical discectomy are not fuly understood yet, but it has been postulated that such a surgical procedure alters the biomechanical conditions at adjacent segments, resulting in increased loading and excessive movement and subsequent disc degeneration. $(3,12,18,22)$.

Based on considerable literary support and clinical experience, most researchers demonstrated that anterior cervical discectomy including interbody fusion is associated with increased clinical and radiographic evidence of ASD $(1,3,5,14,20,22)$. However, the incidence of ASD following simple cervical discectomy is yet unclear. On the other hand, there are only few studies which investigate the development of ASD following posterior cervical foraminotomy and discectomy $(10,11)$.

Therefore, the present study was undertaken to investigate and compare the long-term results of radiologic and clinical evidence of $\mathrm{ASD}$, in and between patients who have undergone anterior or posterior cervical simple discectomy.

\section{MATERIAL and METHODS}

\section{Patients}

A total of 97 patients underwent anterior cervical discectomy (ACD) and posterior cervical discectomy (PCD) in our university hospital between 1986 and 2006. The indications for operative intervention included failure of cervical orthosis, physical therapy, and NSAID agents to relieve radicular symptoms or weakness. Single level, unilateral posterior cervical foraminotomy/discectomy and anterior cervical simple discectomy were performed in individual patients with a soft intervertebral disc. Neither interbody nor posterior fusion was performed in those patients. 46 patients had underwent anterior simple discectomy and 51 posterior laminoforaminotomy/discectomy.
The inclusion criteria for both groups were a previous history of single level simple discectomy at least two years previously. 18 patients were excluded for several reasons: traumatic radiculopathy, previous cervical surgery, cervical instability, reoperation, or concomitant arthrodesis. Thus, 79 patients matched these criteria and 32 of them had anterior and 47 posterior cervical discectomy.

\section{Clinical and radiological analysis}

In the postoperative course, all patients were examined neurologically and follow-up MR scans were performed.

The diagnosis of symptomatic ASD was based on the presence of both new radiculopathy or myelopathy symptoms referable to the adjacent levels. The radiological criteria of ASD was based on the control MRI findings such as loss of discal length and narrowing of interdiscal space, hypertrophy of ligamentum flavum, facetal hypertrophy, ostheophyte formation and varying degrees of narrowness in the spinal canal at adjacent levels. Postoperative MRI findings were compared with preoperative MRI scans or with CT scans in patients who did not have a MRI imaging.

Mean follow-up period was 4.78 (2-10) years in ACD group and 9.85 (2-20) years in (PCD) group.

\section{Statistical analysis}

We evaluated the incidence of symptomatic and radiographic evidence of (asymptomatic) ASD according to the clinical and radiological parameters in each group. We then compared these results of ACD and PCD groups to evaluate which approach was more predominant for ASD.

The results were expressed as mean \pm standard deviation. We selected the statistically significant parameters to correlate with the incidence of ASD by Mann-Whitney $U$ test and Chi-square test. A ' $\mathrm{p}$ ' value of less than 0.05 was considered significant.

\section{RESULTS}

Control MRI studies demonstrated that ASD developed in 57 of total 79 patients (Table I). 25 of the 57 patients were in ACD and 32 patients were in PCD group. Of the 25 patients in ACD group, 8 patients demonstrated symptomatic ASD, and 17 patients were symptom free and demonstrated only radiographic signs of ASD. 11 and 21 of the 32 
Table I: Distribution of the Patients with and without ASD. ( n: number)

\begin{tabular}{|l|c|c|c|c|c|}
\hline & \multicolumn{2}{|c|}{ ASD with MRI findings } & $\begin{array}{c}\text { Patients with } \\
\text { ASD }\end{array}$ & $\begin{array}{c}\text { Patients without } \\
\text { ASD }\end{array}$ & $\begin{array}{c}\text { Total n. of } \\
\text { patients }\end{array}$ \\
\hline & Symptomatic & Asymtomatic & & & \\
\hline ACD & $8(25 \%)$ & $17(53 \%)$ & $25(78 \%)$ & $7(22 \%)$ & 32 \\
\hline PCD & $11(23 \%)$ & $21(44 \%)$ & $32(68 \%)$ & $15(33 \%)$ & 47 \\
\hline TOTAL & 19 & 38 & 57 & 22 & 79 \\
\hline
\end{tabular}

patients in PCD group showed symptomatic and asymptomatic ASD, respectively. (Table I). All symptomatic patients also demonstrated radiographic evidence of ASD in their control MRI scans. 22 of a total of 79 patients demonstrated neither radiographic nor symptomatic ASD.

The average age when ASD was diagnosed was 52 (range, 36 to 69 years) in the ACD and 48 (range, 32-77 years) in PCD groups. The male sex was dominant in both groups. There was no statistical significance between groups in terms of age and sex.

C5-6 and C6-7 levels were the most commonly operated levels in both approaches (Table II). ASD

Table II: Operated Levels in ACD and PCD Groups. (n: number)

\begin{tabular}{|l|c|c|}
\hline Group & Level & n. and \% of Patients \\
\hline ACD & C 4-5 & $6(18.8 \%)$ \\
\hline & C 5-6 & $16(50.0 \%)$ \\
\hline & C 6-7 & $10(31.3 \%)$ \\
\hline PCD & C $4-5$ & $3(6.4 \%)$ \\
\hline & C 5-6 & $23(48.9 \%)$ \\
\hline & C 6-7 & $21(44.7 \%)$ \\
\hline
\end{tabular}

was also found mostly at the C5-6 and C 6-7 segments (Table III).

The mean follow-up period for evidence of ASD was 4.78 (2-10) years in the ACD group and 9.85 (220) years in the PCD group (Table IV). This finding was found to statistically significantly different between the groups (p:0.005) which indicates that the evidence of ASD was observed earlier in the ACD group than the PCD group. Similar results were found when we compared the results at the postoperative periods of $0-5,5-8$ and $>9$ years (Table II). $87.5 \%$ of the patients in the ACD group showed evidence of ASD after the 5th year, whereas $81.8 \%$ of the patients in the PCD group showed similar evidence after the 9th year. Moreover, evidence of ASD was not observed in the PCD groups within the first 4 years (Table V).

The mean follow-up period was 7.63 years for the radiographic evidence of ASD which was longer than the mean follow-up period of 4.67 years in patients with symptomatic evidence of ASD (p:0.003) (Table VI). Therefore, symptomatic evidence of ASD development was found to appear earlier than the radiographic development of ASD for both approaches.

Table III: Cervical Segments which Radiographic and Symptomatic Evidence of ASD are Observed

\begin{tabular}{|l|c|c|c|}
\hline Patients with radiographic evidence of ASD & \multicolumn{3}{|c|}{ Levels } \\
\hline & C4-5 & C5-6 & C6-7 \\
\hline ACD & $2(11.1 \%)$ & $8(47.0 \%)$ & $7(41.1 \%)$ \\
\hline PCD & $2(8.6 \%)$ & $12(57.1 \%)$ & $7(33.3 \%)$ \\
\hline Patients with symptomatic evidence of ASD & C4-5 & C5-6 & C6-7 \\
\hline ACD & $3(37.5 \%)$ & $4(50.0 \%)$ & $1(12.5 \%)$ \\
\hline PCD & $0(0 \%)$ & $6(54.5 \%)$ & $5(45.5 \%)$ \\
\hline
\end{tabular}


Table IV: Minimum, Maximum and Mean Follow up Periods of Patients between Anterior and Posterior Discectomy Groups. ( n: number)

\begin{tabular}{|l|c|c|c|c|}
\hline & n. of patients & Minimum & Maximum & Mean \\
\hline ACD & 32 & 2 years & 10 years & 4.78 years \\
\hline PCD & 47 & 2 years & 20 years & 9.85 years \\
\hline
\end{tabular}

Table V: Profile of Patients with Their Onset of the Dinical Evidence of ASD During the Follow-Up Period. (n: number)

\begin{tabular}{|l|c|c|c|c|}
\hline Patients with clinical evidence of ASD & \multicolumn{3}{|c|}{ Years } & Total n. of patients \\
\hline & $0-4$ & $5-8$ & $>9$ & \\
\hline ACD group & $1(\% 12.5)$ & $4(\% 50)$ & $3(\% 37.5)$ & 8 \\
\hline PCD group & $0(\% 0)$ & $2(\% 18.2)$ & $9(\% 81.8)$ & 11 \\
\hline
\end{tabular}

Table VI: Mean Follow Up Period between Patients with Radiographic and Symptomatic Evidence of ASD. (n: number)

\begin{tabular}{|l|c|c|c|c|}
\hline & n. of patients & Minimum & Maximum & Mean \\
\hline ASD with radiographic evidence & 38 & 2 years & 16 years & 7.63 years \\
\hline ASD with symptomatic evidence & 19 & 4 years & 20 years & 4.67 years \\
\hline
\end{tabular}

Table VII: Distribution of the Symptomatic and Asymptomatic Patients with ASD. (n: number)

\begin{tabular}{|l|c|c|l|}
\hline & Symptomatic ASD & Asymptomatic ASD & \\
\hline ACD & 8 & 17 & $25(31.6 \%)$ \\
\hline PCD & 11 & 21 & $32(40.5 \%)$ \\
\hline Total n. of Patients with ASD & 19 & 38 & 57 \\
\hline Total n. of Patients & & & $79(100 \%)$ \\
\hline
\end{tabular}

Symptomatic ASD developed in 19 and asymptomatic ASD in 38 of a total of 79 patients (p:0.002). Thus, radiographic evidence of ASD was found more commonly than the symptomatic evidence of ASD, whether the choice of operation method was anterior or posterior (Table VII).

We found that simple cervical discectomy performed anteriorly had a similar rate of radiographic and symptomatic ASD with the posterior approach (31.6\% of 79 patients vs $40.5 \%$ of 79 patients, $\mathrm{p}>0.05$ ). Therefore, the evidence of ASD was not found to be statistically significantly different between the groups. There was also no statistically significant difference (p:0.850) when we compared only the symptomatic evidence of ASD between the anterior and posterior group of patients.

\section{DISCUSSION}

Radiologically detected new degenerative changes at levels adjacent to a single-level cervical fusion mass have been demonstrated in series at rates varying from $25 \%$ to $89 \%$ of patients who have undergone cervical fusion $(1,3,13,15)$. In a cited study, Hilibrand, et al. reported a large retrospective series in which patients underwent anterior discectomy and subsequent Smith-Robinson fusion, and the authors concluded that symptomatic ASD occurred at a relatively constant incidence of $2.9 \%$ annually (12). They predicted that new symptomatic disease would occur at an adjacent segment within 10 years of operation in $25.6 \%$ of the patients who underwent anterior cervical fusion. In our series, $25 \%$ of the patients ( 8 of 32 patients) who had been treated anteriorly showed symptomatic ASD as well. 
Besides symptomatic ASD, radiographic evidence of ASD has been defined retrospectively by Goffin et al. They reported that $92 \%$ of their patients who underwent anterior arthrodesis developed progressive ASD (7). In another study, investigators performed MR imaging preoperatively and during a relatively short-term follow-up period (mean duration 17.5 months) and observed accelerated spondylitic changes adjacent to the fused segment; more pronounced degenerative changes occurred in $75 \%$ of the patients (15). In our series, the rate of only radiographic evidence was 53\% following anterior simple cervical discectomy.

Our ASD rates with simple anterior discectomy are similar to those who had undergone anterior cervical fusion. For the cervical spine, there are also data available for comparison of fusion and nonfusion procedures to determine whether the fusion itself might be causative in the development of ASD. For example, Lunsford et al. reported the relatively short follow-up (less than 3 years) of 334 patients who underwent anterior cervical discectomy, many without fusion. Interestingly, they also did not find any difference in the rate of ASD between patients who underwent discectomy with fusion and those who underwent discectomy alone (16). Gore et al. also reported that there was no difference in the incidence of degenerative changes between the operated and the control group at the levels above and below the fusion (8). Therefore, our study may also support the hypothesis that the mobility and the intradiscal pressure of the adjacent disc were increased after single-level simple discectomy in the same manner that it is seen after discectomy with fusion. In a recent study, Robertson et al. investigated and demonstrated the validity of this hypothesis (20). They compared the incidence of radiologically changes and symptomatic adjacent level cervical disc disease after single-level discectomy and subsequent cervical fusion or arthroplasty. The authors demonstrated that maintaining motion rather than fusion will prevent symptomatic ASD and will decrease adjacent level radiological indicators of disease at a 24-month interval.

However, it is difficult to ascertain whether ASD was caused by increased mechanical stress or by natural progression of the degenerative process. Predisposing factors play an important role at this point. One of the most consistent predisposing factor for ASD development in series of anterior cervical fusion is the presence of degenerative changes at adjacent segments before fusion. In their large series, Hilibrand et al. reported that discs associated with some degree of degeneration before fusion were at risk of developing clinically symptomatic ASD during follow-up (12). They also reported that fusions ending at C5 or C6 were at higher risk of developing ASD than fusions ending at other levels. It was also reported that the lower segments (ie, C5C6 , C6-C7) are typically the ones to degenerate and to require subsequent surgical treatment. These lower levels may be vulnerable because of their increased segmental motion and loading demands. In our series, C5-6 and C6-7 were the levels that were operated on more frequently than other levels. In addition, $80 \%$ of our cases operated on via an anterior approach and $90 \%$ of the cases operated posteriorly showed ASD at C5-6 and C6-7 levels as well. Our results also support that lower cervical levels are candidates for adjacent segment disease. This finding of our study and close proximity of the ranges of ASD in our series to anterior discectomy and fusion series may indicate that ASD is a part of a natural progression of the degenerative process. On the other hand, Goffin et al. hypothesized that ASD is caused by operative damage to the anterior longitudinal ligament or the longus colli muscles (6). Moreover, dissection and retraction of the longus colli muscles in conjunction with localization of the disc segment during anterior cervical spine surgery might serve as irritants to ligamentous structures. Ligamentous alterations might lead to local changes in load sharing that affect the dynamic stability of the column (19). This operative manipulation is common for all kinds of anterior approaches to cervical disc disease and therefore may cause further ASD in cervical discectomies with or without fusion.

The chosen surgical approach used for the treatment of cervical spondylosis is reported to have no effect on the development of ASD by some authors. Herkowitz et al. studied 44 patients with 4.5 years of follow-up who had been randomized to anterior cervical discectomy and fusion or posterior foraminotomy without fusion for the treatment of cervical radiculopathy $(11,22)$. In the group undergoing anterior fusion, $41 \%$ developed ASD. Surprisingly, 50\% percent of the patients undergoing posterior foraminotomy without fusion had 
evidence of adjacent level degeneration. Henderson and coworkers performed 846 discectomies through a posterior laminoforaminotomy in 736 patients (10). In their series, the incidence of ASD was 3.9\% per year, which is quite similar to other large series of anterior arthrodesis with an incidence ranging from $2 \%$ to $4 \%$. These observations raised the question of the role of surgery in the development of ASD. We also found no significant difference for the development of ASD between patients who underwent anterior single level simple discectomy or posterior laminoforaminotomy and discectomy. Moreover, our study was unique in a literature search that specifically compared the anterior and posterior cervical approach for simple discectomy without fusion to investigate the incidence of further ASD. The main difference between anterior and posterior approach in our study by means of ASD is that symptomatic evidence of ASD was observed earlier in the anterior group than the posterior group.

Several series have studied the prevalence of radiological degenerative findings in subjects with evidence of cervical myeloradiculopathy $(3,9,14,17)$. The authors reported that there was no correlation between the development of ASD and the onset of new clinical symptoms referable to the radiographic changes. However, it is true that many clinical follow-up studies of patients undergoing anterior cervical discectomy and fusion have demonstrated that some patients undergoing anterior cervical fusion do appear to develop symptomatic ASD. Bohlman, Gore and Williams reported in different studies that, $9 \%, 14 \%$ and $17 \%$ of their patients undergoing anterior cervical decompression and fusion developed ASD requiring additional surgery, respectively. $(2,8,23)$. These three studies suggested that the annual incidence of ASD requiring additional surgery appears to be between $1.5 \%$ and $4 \%$. In our study, all symptomatic patients with radicular pain responded to an aggressive regimen of conservative therapy. None of our patients developed onset of motor deficit, persistent disabling pain, progressive deformity, myelopathic signs and symptoms, or clinical instability and therefore none of them required surgical intervention.

In conclusion, it appears that both anterior and posterior single level simple discectomy have similar rates for ASD based on the available clinical and radiographic evidence of ASD analyzed in this study. Anterior single level simple cervical discectomy may reach the same rate of ASD following anterior single level cervical discectomy with fusion. Radiographic evidence of ASD is a significantly more common finding than symptomatic evidence of ASD. Radiographic and symptomatic evidence of ASD was found to appear earlier in patients who underwent anterior cervical discectomy than the posterior approach. Symptomatic evidence of ASD also appears earlier than the radiographic evidence of ASD.

\section{REFERENCES}

1. Boden SD, McCowin PR, Davis DO, Dina TS, Mark AS, Wiesel $\mathrm{S}$ : Abnormal magnetic-resonance scans of the cervical spine in asymptomatic subjects. A prospective investigation. J Bone Joint Surg Am 72: 1178-1184, 1990

2. Bohlman HH, Emery SE, Goodfellow DB, Jones PK: Robinson anterior cervical discectomy and arthrodesis for cervical radiculopathy. Long-term follow-up of one hundred and twenty-two patients. J Bone Joint Surg Am 75:1298-1307, 1993

3. Cherubino P, Benazzo Fi Borromeo U, Perle S: Degenerative arthritis of the adjacent spinal joints following anterior cervical spinal fusion: Clinicoradiologic and statistical correlations. Ital J Orthop Traumatol 16:533-543, 1990

4. Clements DH, O'Leary PF: Anterior cervical discectomy and fusion. Spine 15:1023-1025, 1990

5. Chiles BW, Leonard MA, Choudhri HF, Cooper PR: Cervical Spondylotic myelopathy: patterns of neurological deficit and recovery after anterior cervical decompression. Neurosurgery 44;762-769, 1999

6. Goffin J, Loon JV, Calenberg FV, Plets C: Long-term results after anterior cervical fusion and osteosynthetic stabilization for fractures and / or dislocations of the cervical spine. J Spinal Disord 8:500-508, 1995

7. Goffin J, Geusens E, Vantomme N, Quintens E, Waerzeggers $Y$, Depreitere B, Van Calenbergh F, Van Loon J: Long term follow-up after interbody fusion of the cervical spine. J Spinal Disord Tech 17:79-85, 2004

8. Gore DR, Sepic SB: Anterior cervical fusion for degenerated or protruded discs: a review of one hundred forty-six patients. Spine 9(7):667-671, 1984

9. Gore DR, Gardner GM, Sepic SB, Murray MP: Roentgenoraphic findings following anterior cervical fusion. Skeletall Radiol 15:556-559, 1986

10. Henderson CM, Hennessy RG, Shuey HM Jr, Shackelford EG : Posterior-lateral foraminotomy as an exclusive operative technique for cervical radiculopathy: A review of 846 consecutively operated cases. Neurosurgery 13:504-512, 1983

11. Herkowitz HN, Kurz LT, Overholt DP: Surgical management of cervical soft disc herniation: A comparison between anterior and posterior approach. Spine 15(10):1026-1030, 1990

12. Hilibrand AS, Carlson GD, Palumbo MA, Jones PK, Bohlman $\mathrm{HH}$ : Radiculopathy and myelopathy at segments adjacent to the site of a previous anterior cervical arthrodesis. J Bone Joint Surg Am 81:519-528, 1999 
13. Humphreys SC, Hodges Sd, Patwadhan A, Eck JC, Covington LA, Sartori M: The natural history of the cervical foramen in symptomatic and asymptomatic individuals aged $20-60$ years as measured by magnetic resonance imaging. A descriptive approach. Spine 23:2180-2184, 1998

14. Hunter LY, Braunstein EM, Bailey RW: Radiographic changes following anterior cervical fusion. Spine 5:399-401, 1980

15. Kulkarni V, Rajshekhar V, Raghuram L: Accelerated spondylotic changes adjacent to the fused segment following central cervical corpectomy: magnetic resonance imaging study evidence. J Neurosurg 100 (1 Suppl):2-6,2004

16. Lundsford LD, Bissonette DJ, Jannettta PJ, Sheptak PE, Zorub DS: Anterior surgery for cervical disc disease, part1: Treatment of lateral cervical disc herniation in 253 cases. J Neurosurg 53:1-11, 1980

17. Matsumoto M, Fujimura $Y$, Suziki N, Nishi $Y$, Nakamura M, Yabe Y, Shiga H: MRI of cervical intervertebral discs in asymptomatic subjects. J Bone Joint Surg Br 80:19-24, 1998

18. Michelle JC, Ecker RD, Krauss WE, McClelland RL, Dekutoski MB: Same-segment and adjacent segment disease following posterior cervical foraminotomy. J Neurosurg Spine 6:5-9, 2007

19. Murphey F, Simmons JC, Brunson B: Surgical tretment of laterally ruptured cervical disc. Rewiev of 648 cases, 1939 to 1972. J Neurosurg 38: 679-683, 1973

20. Robertson JT, Papadopulos SM, Traynelis VC: Assessment of adjacent-segment disease in patients treated with cervical fusion or arthroplasty: A prospective 2-year study. J Neurosurg Spine 3:417-423, 2005

21. Scoville WB: Types of cervical disc lesions and their surgical approaches. JAMA 196: 223-224, 1995

22. Truumees E, Herkowitz HN: Adjacent segment degeneration in the cervical spine: Incidence and management. Semin Spine Surg 4:373-383, 1999

23. Williams JL, Allen MB, Harkess JW: Late results of cervical discectomy and interbody fusion: Some factors influencing the results. J Bone Joint Surg 50A:277-286, 1968 